\title{
Carbon stocks in semi-arid pastoral ecosystems of northern Kenya
}

\author{
Bulle Hallo Dabasso ${ }^{1 *}$, Zerihun Taddese ${ }^{2}$ and Dana Hoag ${ }^{3}$
}

\begin{abstract}
Data on carbon stocks in pastoral ecosystems is important for assessing their contribution for offsetting emissions of greenhouse gases through carbon storage. Such data also provides baseline information to determine if pastoral grazing management can be engaged for carbon credit trading. Real and accurate carbon data is scarce. Much of the available data is often based on limited assessment of carbon stocks in a specified range unit, which fails to capture the spatial and temporal heterogeneity that characterizes pastoral ecosystems. In this study, we considered heterogeneity of semi-arid pastoral ecosystems of northern Kenya by aggregating sample results taken during wet and dry seasons and from various landscape types. We found average carbon stocks of $93.01 \pm 15.72$ tonnes ha-1 across landscape types and seasons. The measured amount of stored carbon is sufficient to have an important contribution in controlling the atmospheric concentration of greenhouse gases; it also indicates a potential to improve pastoralist livelihoods through carbon credit trading. However, more research would be required in order to qualify pastoralists for carbon credits since the data collected in this study is not sufficient to determine the change in carbon storage by grazing practices. In addition, uncertainty in the value of carbon credits needs to be considered to avoid relying on a risky prospect.
\end{abstract}

Keywords: Carbon stocks; Green house gases; Landscape types; Northern Kenya; Pastoral ecosystems

\section{Background}

Carbon dioxide $\left(\mathrm{CO}_{2}\right)$ is considered one of the greenhouse gases (GHGs) that has been associated with global climate change. Since pre-industrial times, global $\mathrm{CO}_{2}$ has increased by $40 \%$ (IPCC 2013). Although empirical evidence on the contribution of GHGs in causing atmospheric warming is not certain (see Kobash et al. 2011; Mangini et al. 2005), land uses that offset atmospheric $\mathrm{CO}_{2}$ emissions through carbon storage in plants and soils are commonly considered environmentally friendly (e.g. Lal 2001). The potential of rangelands to store carbon in soils and vegetation has been acknowledged in many studies (e.g. IPCC 2007) and lies within the natural state of rangelands or rangelands moderately disturbed by grazing (Perez-Quezada et al. 2011). Nevertheless, in pastoral ecosystems ${ }^{\mathrm{a}}$ characterized by communal grazing, carbon storage potential is poorly understood. Continuous grazing in pastoral ecosystems is often thought to reduce primary productivity or species composition; therefore,

\footnotetext{
* Correspondence: bulledabasso@yahoo.com

'Kenya Agriculture Research Institute, P.O. Box 147, Marsabit, Kenya Full list of author information is available at the end of the article
}

no substantial carbon stocks are assumed (Piñeiro et al. 2010). This assumption is not supported by accurately collected carbon data, as the results of this study will show. Carbon stocks are often measured in a single assessment of a certain range environment. However, pastoral ecosystems are heterogeneous, both in spatial and temporal dimensions (Qi et al. 2000). The spatial heterogeneity results from the variations in micro-climate, physical landforms and precipitation, and creates a skewed distribution of soil moisture and nutrients that influence carbon storage (Aguiar and Sala 1999). Temporal heterogeneity arises from seasonal difference in net primary productivity influenced by rainfall patterns and the variation in the grazing condition (Nori 2006). More often than not, attempts to estimate carbon stocks in pastoral ecosystems seldom consider the challenges emanating from rangeland heterogeneity and therefore assume uniformity. As Kratli and Schareika (2010) observed, an average of measurements taken from different sampling points to represent rather heterogeneous environments is misleading since asymmetric distribution of carbon that characterizes pastoral ecosystems

\section{实}


is not captured. Studies that use this methodological approach are therefore misleading and result in incomplete accounting of carbon stock estimates in rangelands.

Environmental dynamics in pastoral ecosystems has already led to the development of at least two contrasting ecological models, with different implications for its capacity to store carbon in eastern Africa. (Coppock 1994), for example, describes the pastoral ecosystem in southern Ethiopia as being an equilibrium state where the major determinants for vegetation change is grazing. Illius and O'Connor (1999) made similar descriptions of the arid and semi-arid grazing systems. These views, however, contrast with those of other authors who describe systems in eastern Africa as non-equilibrium (Behnke et al. 1993; Ellis and Swift 1988; Oba et al. 2003; Scoones and Graham 1994), where change in vegetation is driven by non-density-dependent factors such as rainfall. However, there is a possibility that the two models are relevant in what is described as a continuum between equilibrium and non-equilibrium (Derry and Boone 2010; Vetter 2005).

Limited understanding about the amount of carbon stocks in pastoral ecosystems thus results from a failure to consider spatial and temporal environmental dynamics. This poses challenges for policy development to promote, manage or protect pastoralism to safeguard the atmospheric environment from GHG emissions, in addition to providing local pastoralists with a reasonable livelihood. Consequently, there has been a general development of replacing pastoralism with other land uses without looking at associated environmental implications (Behnke and Kerven 2013).

This study seeks to assess carbon stocks in semiarid pastoral ecosystems, commonly perceived to have been degraded by grazing. We purposively selected a site in northern Kenya with adequate heterogeneity in spatial characteristics, and we sampled across wet and dry seasons to capture temporal variability. The site was classified into landscape types depending on vegetation life form $^{\mathrm{b}}$ and systematically assessed for carbon stocks. We proposed the following two research questions:

- What is the amount of carbon stocks in semi-arid pastoral ecosystems of northern Kenya?

- How does the spatial and temporal heterogeneity of the environment influence the amount of carbon stocks in pastoral ecosystems?

It is also important to determine the potential that these lands hold for selling carbon credits, which potentially provide a much needed income stream to local pastoralists. While we did not have the appropriate data to address this question, we took the first steps by quantifying how much carbon is stored on a continuously grazed system. More research would be required to determine the impact of grazing on storage and the viability of carbon markets to provide reliable income.

\section{Study area}

This study was conducted in Marsabit Central grazing land, located along the topographical gradient of Marsabit Mountain of northern Kenya. The topographical gradient stretches from the upper side of Marsabit Mountain forest through the transitional zone to the foot slopes (Figure 1). Diverse vegetation that consists of grassland, shrubland and woodland are found along the topographical gradient. Vegetation dominated with grasses and dense shrubs are found on the upper side of the slope, while scattered trees intercepted with some scrub vegetation are found on the foot slope. Like the vegetation, soil types are also diverse, ranging from deep and well-weathered soils with clay-like texture found on the upper slope to sandy loam type of soils with moderate weathering on the lower slope.

The area is semi-arid with annual rainfall ranging from 400 to $750 \mathrm{~mm}$, distributed bio-modally between

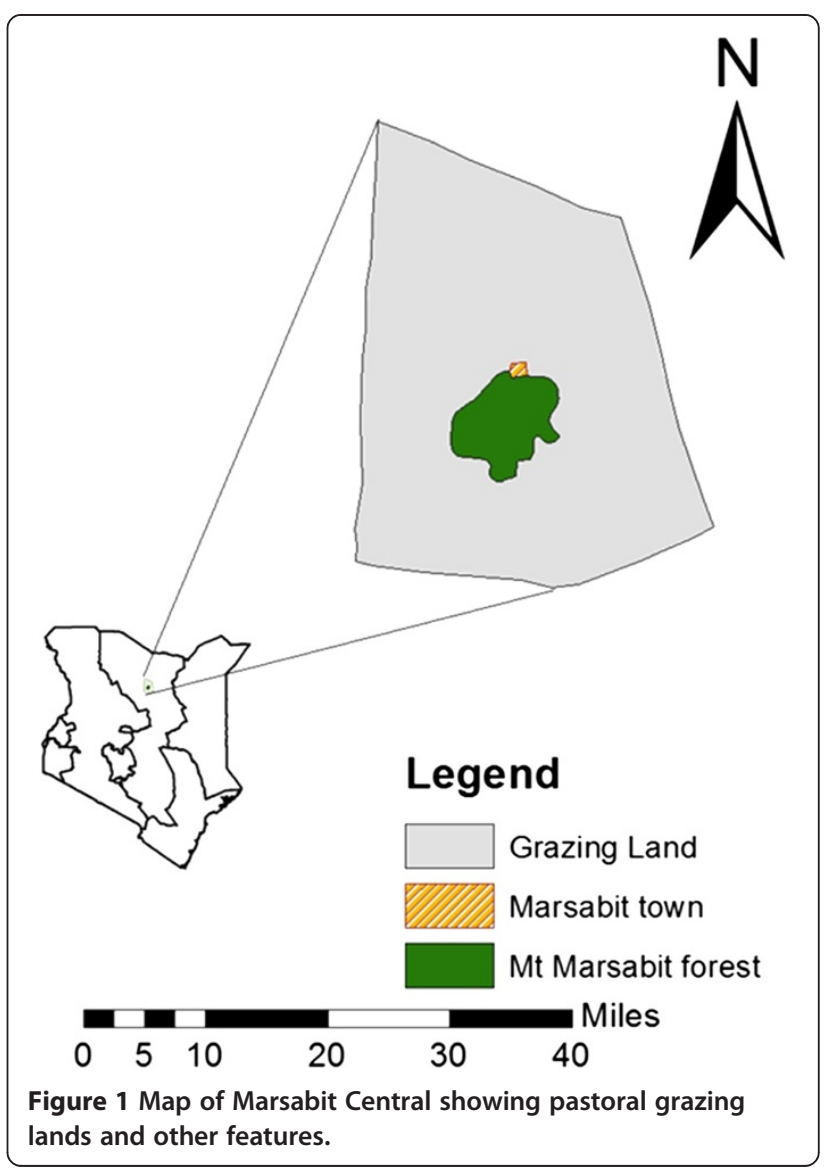


long rainy and short rainy seasons. The prevailing livelihood option is pastoralism where cattle, sheep, goats and camels are kept in communal grazing lands. Livestock form key individual or family assets for food and income, and also for defining social and cultural identity. A semi-sedentary system of livestock production is the common practice where small herds are left at home for milking and for other domestic needs while the remaining herds are kept in strategic movements between landscapes, to opportunistically use available resources.

Livestock production is faced with numerous challenges including continuous loss of grazing lands and frequent feed shortages especially during drought conditions. Like most parts of northern Kenya, herd mobility faces continuous deprivation of access rights resulting from land privatization by individuals and other land users (Lengaiboni et al. 2010). The continuous loss of land, coupled with frequent drought occurrences, had made a large number of pastoralists to adopt a sedentary lifestyle (Little 1985). Nonetheless, recent recognition of communal land tenure rights by the Kenyan constitution might reverse the trend of land loss to private investors (Odote 2013). Land is communally owned by a variety of ethnic groups, not limited to Borana, Rendille and Gabra. A large proportion of each ethnic group can be rated as poor earning less than $\$ 2$ a day (Hogg 1986). Poverty is directly linked to limited government commitment in promoting pastoralism as a viable and sustainable land use (Hesse and MacGregor 2006). As observed by Haro et al. (2004), both colonial and even early post-Independence governments thought that northern Kenya pastoralists accumulate more herds beyond optimal carrying capacity from an environmental perspective and therefore encouraged destocking. Herd accumulation was assumed to result in overgrazing and cause the problem of land degradation (Lamprey 1983).

Environmental destruction by pastoralism as a land use option is rarely substantiated (Roba and Oba 2008; Ward et al. 1998). The perception of pastoralism as an environmentally destructive livelihood may mask carbon storage potential in pastoral ecosystems. This is despite positive implications of grazing already found due to soil carbon storage related to nutrient cycling and plant photosynthesis. For example, comparative soil carbon evaluation between grazed and non-grazed pastures in the semi-arid rangelands of America showed positive implications of grazing in soil organic matter formation and accumulation (Reeder and Schuman 2001).

\section{Methods}

A survey of the study site was conducted during which samples of grassland, woodland and shrubland vegetation were identified and selected. ${ }^{\mathrm{c}}$ Each major vegetation type was considered a landscape type in the study. The landscape types were replicated three times $(n=3)$. Within each landscape type was a permanent plot of $400 \mathrm{~m} \times$ $400 \mathrm{~m}$, established using a Global Positioning System (GPS) and its borders marked with paint for future reference. From the centre of permanent plots, transects of $200 \mathrm{~m}$ in east, west, north and south directions were laid out. At intervals of $30 \mathrm{~m}$, nested sub-plots (of $10 \times 10 \mathrm{~m}$ for trees, $4 \times 4 \mathrm{~m}$ for shrub and $1 \times 1 \mathrm{~m}$ for herbaceous) were established. Woody carbon $(n=72)$, herbaceous carbon $(n=72)$ and soil carbon $(n=72)$ were assessed for each landscape type within its nested sub-plots. The assessments were done for two consecutive seasons of wet and dry in 2013.

\section{Woody carbon assessment}

Using a flexible tape, the diameter at chest height (DCH) (1.3 $\mathrm{m}$ above the ground) of all the trees within $10 \times$ $10 \mathrm{~m}$ plots and basal diameters (BD) of all shrubs within the $4 \times 4 \mathrm{~m}$ plots were taken. Both $\mathrm{DCH}$ and $\mathrm{BD}$ were recorded in prepared data sheets, and carbon estimates within each plant were done using allometric equations as described by (Henry et al. 2011). The following allometric equation was applied:

$$
\begin{aligned}
\text { Trees }: \mathrm{Y} & =0.1975 x \mathrm{DCH} 1.1859, \\
\text { Shrubs }: \mathrm{Y} & =0.1936(x 1.1654)
\end{aligned}
$$

where

$Y=$ Fresh weight of trees/Shrub biomass $(\mathrm{kg})$.

$x=\mathrm{DCH} / \mathrm{BD}(\mathrm{cm})$.

The results of allometric equation only provide fresh biomass estimates. In order to measure dry biomass, the results are multiplied by $60 \%$ and the carbon content taken as $50 \%$ of the dry biomass weight (Brown et al. 1999). Root carbon estimates were $20 \%$ of above-ground carbon (Cairns et al. 1997). Both above-ground and below-ground carbon estimates within nested plots were converted to carbon in tonnes per hectare $(1$ tonne $=$ $1,000 \mathrm{~kg}, 1$ ha $=10,000 \mathrm{~m}^{2}$ ).

\section{Herbaceous carbon assessment}

A prepared quadrant of $1 \mathrm{~m}^{2}$ was placed in each of $0.5 \times 0.5 \mathrm{~m}$ sub-plot. Herbaceous materials within $1 \mathrm{~m}^{2}$ were then clipped at $1-\mathrm{cm}$ stubble height. Clipped materials, together with litters, were put in sample paper bags and their fresh weights recorded. Herbaceous root materials were also excavated and fresh weight recorded. Care was taken to collect and separate fine roots from soils. Both the above-ground and root materials of herbaceous plants were oven-dried at $80^{\circ} \mathrm{C}$ for $48 \mathrm{~h}$. Herbaceous carbon contents were calculated as $50 \%$ of oven-dried herbaceous biomass. The results were recorded in a prepared data sheet. Sample results were then converted into carbon tonnes per hectare ( 1 tonne $=1,000,000 \mathrm{~g}$ ). 


\section{Assessment of soil carbon}

Soil sampling was done in each $0.5 \times 0.5 \mathrm{~m}$ sub-plot at a $30-\mathrm{cm}$ depth using a soil auger whose volume head had been pre-determined using the formula below:

$$
V=\pi r^{2} h
$$

where

$$
\begin{aligned}
& V=\text { volume head } \\
& \pi=3.14 \mathrm{~cm} \\
& r=\text { head radius }(\mathrm{cm}) \\
& h=\text { head height }(\mathrm{cm})
\end{aligned}
$$

Soil samples were labeled and oven-dried at $80^{\circ} \mathrm{C}$ for $48 \mathrm{~h}$. The oven-dried samples were then sieved by passing through 2-mm sieve. Bulk density of each soil sample was then calculated using the following formula;

$$
\mathrm{BD}_{\text {sample }}=\mathrm{ODW}_{\text {sample }} / \mathrm{VAD}
$$

where

$\mathrm{BD}_{\text {sample }}$ is the bulk density of soil sample $\left(\mathrm{g} \mathrm{cm}^{-3}\right)$ $\mathrm{ODW}_{\text {sample }}$ is the weight of oven-dried sample (g)

VAD is the volume of soil auger head $\left(\mathrm{cm}^{3}\right)$

The results were recorded in a prepared data sheet. An estimated 10-g sample of sieved soil was taken for carbon content analysis. Soil carbon (C) was determined through oxidation as described by Anderson and Ingram (1993). The carbon concentrations were read on the spectrophotometer at $600 \mathrm{~nm}$. The concentrations (\%) obtained from the laboratory were used to calculate carbon mass per unit area. Carbon contents in the samples were calculated using the indicated formula below:

$$
\mathrm{C}\left(\mathrm{g} \mathrm{cm}^{-3}\right)=\left(\mathrm{BD}_{\text {sample }} \times \mathrm{C} \%\right)
$$

where

$\mathrm{BD}_{\text {sample }}$ is the bulk density of soil sample $\left(\mathrm{g} \mathrm{cm}^{-3}\right)$

$\mathrm{C} \%$ is the percentage carbon concentration of the sample
Sample carbon content was multiplied by soil sampling depth $(30 \mathrm{~cm})$ to carbon content per unit surface area using the formula:

$$
\operatorname{CSA}\left(\mathrm{g} \mathrm{cm}^{-2}\right)=\mathrm{C}\left(\mathrm{g} \mathrm{cm}^{-3}\right) \times \mathrm{SD}(\mathrm{cm})
$$

where

CSA = carbon per unit of surface area $\left(\mathrm{g} \mathrm{cm}^{-2}\right)$

$\mathrm{C}=$ carbon content in the sample $\left(\mathrm{g} \mathrm{cm}^{-3}\right)$

$\mathrm{SD}=$ soil sampling depth $(\mathrm{cm})$, taken as $30 \mathrm{~cm}$

The results were converted into carbon tonnes per hectare using the ratio of hectare to $\mathrm{cm}^{-2}(1: 1,000,000)$.

\section{Data analysis}

Aggregations of carbon from various carbon pools (above-ground herbaceous, below-ground herbaceous, above-ground woody, below-ground woody, soil carbon) were done and averages calculated for each landscape type. The least significant difference (LSD) was used to separate the means. To evaluate the effect of landscape type and season on the carbon level of various carbon pools, a general linear model (GLM) was used and significant difference accepted at 5\% level of probability error. The GLM analysis procedure is as follows (SAS 1999, version 8):

$$
\text { Model : } y_{i j k}=\mu+\rho_{i}+\alpha_{j}+\varepsilon_{i j k},
$$

where

$y_{i j k}$ is the observation from the $i j$ combination of factors, landscape type and season

$\mu$ is the overall mean of carbon content

$\rho_{i}$ is the effect of $i$ factor of landscape type on carbon content

\begin{tabular}{|c|c|c|c|c|c|c|}
\hline \multirow{2}{*}{$\begin{array}{l}\text { Landscape } \\
\text { type }\end{array}$} & \multicolumn{6}{|c|}{ Carbon level (tonnes $\mathrm{ha}^{-1}$ ) } \\
\hline & $\begin{array}{l}\text { Above-ground } \\
\text { herbaceous carbon }\end{array}$ & $\begin{array}{l}\text { Below-ground } \\
\text { herbaceous carbon }\end{array}$ & $\begin{array}{l}\text { Above-ground } \\
\text { woody carbon }\end{array}$ & $\begin{array}{l}\text { Below-ground } \\
\text { woody carbon }\end{array}$ & $\begin{array}{l}\text { Soil carbon } \\
\text { (at } 0 \text { - to } 30-\mathrm{cm} \text { depth) }\end{array}$ & $\begin{array}{l}\text { Total } \\
\text { carbon }\end{array}$ \\
\hline $\begin{array}{l}\text { Grassland } \\
(n=3)\end{array}$ & $0.28 \pm 0.04$ & $0.44 \pm 0.03$ & $2.21 \pm 0.825$ & $0.44 \pm 0.16$ & $92.86 \pm 14.62$ & $96.23 \pm 14.78$ \\
\hline $\begin{array}{l}\text { Shrubland } \\
(n=3)\end{array}$ & $0.53 \pm 0.04$ & $0.17 \pm 0.03$ & $6.48 \pm 0.83$ & $1.3 \pm 0.16$ & $107.22 \pm 14.84$ & $115.7 \pm 15.00$ \\
\hline $\begin{array}{l}\text { Woodland } \\
(n=3)\end{array}$ & $0.32 \pm 0.04$ & $0.17 \pm 0.03$ & $4.63 \pm 0.83$ & $0.93 \pm 0.16$ & $78.93 \pm 15.63$ & $85.15 \pm 15.28$ \\
\hline
\end{tabular}

$\alpha_{j}$ is the effect of $j$ factor of season on carbon content $\varepsilon_{i j k}$ is the error term

\section{Results and discussion}

Carbon stocks in the grazed landscapes of Marsabit Central Results of carbon stocks in various landscape types are presented in Table 1 . The results are averages from wet and dry season carbon storage and disaggregated into

Table 1 Carbon stocks in the grazed landscapes of Marsabit Central 
landscape carbon pools. In Table 1, summation of carbon in every carbon pool was also presented as total carbon for each landscape type. Calculations of the total carbon stocks across all landscape types showed an average carbon level of $93.01 \pm 15.72$ tonnes $\mathrm{ha}^{-1}$. The result is consistent with carbon stocks for grazing areas of sub-Saharan Africa (see Matieu 2010). The measured amount of stored carbon exists under communal grazing management in the study area's semi-arid pastoral ecosystems. Pastoral grazing management through herd mobility across landscape types might have helped the maintenance of stored carbon. The conversion of measured carbon stocks in Marsabit Central grazing lands is equivalent to 341.35 tonnes $\mathrm{ha}^{-1}$ of carbon dioxide, which is considered as one of the greenhouse gases. ${ }^{d}$ This therefore depicts the importance of pastoral ecosystems in preventing the release of carbon dioxide that could have an influence on climate.

Disaggregation of the above amount of carbon stocks into carbon levels for various carbon pools indicate that $98.39 \%$ of the carbon is stored in the soils, $1.2 \%$ in the above-ground woody vegetation, $0.2 \%$ in woody roots, $0.12 \%$ in above-ground herbaceous and $0.07 \%$ in herbaceous roots. Any anthropogenic activities that might have adverse effects on soils will therefore have significant implications in reducing carbon stocks in the grazing lands. Cultivation of grazing lands is already found to reduce soil carbon stocks due to disturbance of the soil surface (Jiao et al. 2009). A study by Wang et al. (2008) in Inner Mongolia, observed a $22 \%$ reduction in soil carbon stocks when grazing land was converted into cultivated land. It is therefore important to guard grazing lands from degradation that will eventually interfere with soil condition.

The contribution of pastoral grazing systems is very significant when the vastness of the global pastoral ecosystems is considered. Pastoral ecosystems cover 40.5\% of the terrestrial ecosystem, equivalent to 5,250 $\mathrm{M}$ ha (White et al. 2000). The contribution of pastoral ecosystems in offsetting atmospheric greenhouse gases through carbon storage is however seldom appreciated. Instead, livestock production in the rangelands has been accused of emitting greenhouse gases through enteric fermentation (see Gerber et al. 2013; Steinfeld et al. 2006). The contribution of livestock production in rangelands to provide ecosystem services by maintaining an important amount of carbon stocks in the soils and vegetation should be considered in order to balance the associated potentially adverse effects of greenhouse gas emissions (see also Herrero et al. 2009).

\section{Effect of landscape types on the carbon stocks of Marsabit Central grazing lands}

Effects of landscape types were significant on carbon stocks for all carbon pools of the landscapes (all $P<0.05$ ) - see
Table 2. The effects are also significant on average carbon stocks at the landscape level $(P<0.05)$. Shrubland had more total carbon stocks than both grassland and woodland landscape types (Table 1 above). Woodland had the least carbon stocks. Woodland possibly had less herbaceous vegetation cover, which does not facilitate an adequate rate of plant material decomposition into the soils for soil carbon formation (see also Kurgat 2011). Landscape types with more herbaceous cover are often thought to have a relatively higher rate of organic matter decomposition compared to woody types of vegetation (Rice 2005). These effects of landscape types on rangeland carbon stocks are also a likely demonstration of rangeland ecological variability in terms of differences in the spatial distribution of plant communities. Rangelands are generally considered mosaics of diverse ecological conditions created by spatial variation in soils, topography and micro-climate (Scoones 1999). The ecological variations result in asymmetric distribution of carbon stocks. Assessment of carbon content or biomass productivity should therefore consider the heterogeneous nature of the environment to avoid errors arising from asymmetric resource distribution (Kratli and Schareika 2010).

\section{Effects of seasons on the carbon stocks of Marsabit Central grazing lands}

Unlike the landscape types above, seasonal effects on the carbon stocks are not significant for most carbon pools (all $P>0.05$ ). Season only influenced the above-ground herbaceous carbon pool (Table 3 below). The seasonal difference in carbon stocks is a proxy for assessing the implications of grazing intensity on rangeland carbon. The wet season is commonly viewed as a period of less grazing pressure because of an abundance of grazing resources initiated by enhanced soil moisture. On the other hand, the dry season is seen as a period of resource scarcity arising from a lack of or limited soil moisture. Evaluation of seasonal differences in the carbon stocks of rangelands will thus help in understanding implications of temporal variability of rangeland carbon. In this study, lack of significance implies that livestock

Table 2 Effects of landscape types on carbon stocks of Marsabit Central grazing lands

\begin{tabular}{llll}
\hline Carbon pool & $\begin{array}{l}\text { Degree of } \\
\text { freedom }(\boldsymbol{d} \boldsymbol{f})\end{array}$ & $\boldsymbol{P}$ value & $\boldsymbol{R}^{\mathbf{2}}$ \\
\hline Above-ground herbaceous carbon & 2 & 0.0001 & 0.050251 \\
Below-ground herbaceous carbon & 2 & 0.0001 & 0.213012 \\
Above-ground woody carbon & 2 & 0.0001 & 0.062989 \\
Below-ground woody carbon & 2 & 0.0048 & 0.025326 \\
Soil carbon (at 0 to 30 cm) & 2 & 0.0001 & 0.241363 \\
Total carbon & 2 & 0.0001 & 0.170183 \\
\hline
\end{tabular}


Table 3 Seasonal variations of carbon stocks of Marsabit Central grazing lands

\begin{tabular}{llll}
\hline Landscape carbon pool & \multicolumn{2}{l}{ Seasonal variation } & \multirow{2}{*}{$\boldsymbol{P}$ value } \\
\cline { 2 - 3 } & Wet & Dry & \\
\hline $\begin{array}{l}\text { Above-ground herbaceous } \\
\text { carbon }\end{array}$ & $0.49 \pm 0.02$ & $0.39 \pm 0.02$ & 0.0027 \\
Below-ground herbaceous carbon & $0.27 \pm 0.01$ & $0.24 \pm 0.01$ & 0.1208 \\
Above-ground woody carbon & $4.43 \pm 0.47$ & $4.4 \pm 0.47$ & 0.9833 \\
Below-ground woody carbon & $0.88 \pm 0.0957$ & $0.89 \pm 0.0957$ & 0.9844 \\
Soil carbon & $93.32 \pm 9.06$ & $87.5 \pm 9.06$ & 0.0926 \\
Total carbon & $99.39 \pm 9.1576$ & $93.42 \pm 9.1576$ & 0.0942 \\
\hline
\end{tabular}

grazing and soil moisture variation did not impact the carbon stocks of the rangelands. These findings are consistent with other studies (e.g. Schuman et al. 2002; Reeder and Schuman 2002). However, it is crucial to note that the impact of grazing and soil moisture gradient can be complex, depending on the type of ecosystem in question. As suggested by Piñeiro et al. (2010), soil carbon can decrease, increase or not change depending on the ecological condition. These findings should be understood in the context of semi-arid ecosystems with annual precipitation of 400 to $750 \mathrm{~mm}$. A more elaborate carbon measurement repeated over series of years covering periods of dry and wet seasons is necessary to better understand the effects of seasons on rangeland carbon stocks.

\section{Conclusions and recommendations}

In this study, we have measured carbon stocks in a case study of semi-arid pastoral ecosystems under communal and mobile grazing management, considering the spatial and temporal heterogeneity of range environments. The variation of carbon stocks with landscape types affirms the need to consider asymmetric distribution of range resources in the assessment of rangeland carbon content. In our aggregation of sample results from varying landscape types and seasons, we found $93.01 \pm 15.72$ tonnes of carbon ha ${ }^{-1}$ stored in Marsabit Central grazing lands of northern Kenya. Conversion of the measured level of carbon into carbon dioxide equivalent depicted the importance of these kinds of pastoral ecosystems in offsetting atmospheric greenhouse gases that could influence the global climate. Carbon stocks have been possibly maintained by pastoralists' grazing practices, which are characterized by herd mobility over diverse grazing landscapes to utilize the patchiness of range resources. Upholding these grazing practices will reinforce the contribution of pastoral ecosystems in protecting the atmospheric environment. Furthermore, the largest proportions of carbon stocks were found in the soils, meaning that any alternative land use to pastoralism that exposes soil carbon would have substantial adverse environmental effects.
Carbon credit trading could be an important source of income to improve the livelihoods of pastoralists whose grazing practices maintained substantial amount of carbon stocks in extensive rangelands. But carbon markets require proof of additional storage to existing carbon stocks, which has not been shown in this study. Further research should therefore focus on assessing grazing practices that facilitate additional carbon storage so that pastoralists can qualify for carbon credits; research is also needed to understand whether such improvement in their incomes can make pastoralism more sustainable in the future. Uncertainty in the value of carbon credits needs to be considered as well, to avoid relying on a risky prospect. This study has established a baseline in a case study of northern Kenya, of carbon stocks stored in soils and vegetation. In future, this case study area can be monitored, if grazing practices that encourage additional carbon storage and carbon credit trade are established and adopted.

\section{Endnotes}

'The term 'pastoral ecosystem' is widely used in this study to depict the role pastoralism has played in shaping the environment. It is interchangeably used with the word 'rangeland' or 'grazing land'.

${ }^{\mathrm{b}}$ The vegetation life form assessed included grassland, shrubland and woodland.

${ }^{\mathrm{c}}$ Classification of vegetation types was according to the method used by Pratt and Gwynne (1977). Grassland is taken as an area dominated by grasses and herbs with woody canopy cover of less than $2 \%$; woodland is an area dominated by woody plants that grow up to $18 \mathrm{~m}$ in height with not less than 20\% canopy cover. Shrubland is an area dominated by woody plants of not more than $6 \mathrm{~m}$ in height with canopy cover of not less than $20 \%$.

${ }^{\mathrm{d}} \mathrm{A}$ tonne of carbon is equivalent to 3.67 tonnes of carbon dioxide (see Niles et al. 2010; Tennigkeit and Wilkes 2008).

\section{Competing interests}

The authors declare that they have no competing interests.

\section{Authors' contributions}

BHD developed the concept, carried out the field data collection and data analysis, and drafted the manuscript. TZ and DH made comments on the manuscript. All authors read and approved the final manuscript.

\section{Acknowledgements}

This study was funded by U.S Agency for International Development through Feed the Future Innovation Lab for Collaborative Research on Adapting Livestock System to Climate Change. The authors acknowledge the contribution to field data collection by Mr. Hussein Walaga and Mr. Peter Geikuku. Study logistical support was provided by the Kenya Agricultural Research Institute, Marsabit research station.

\section{Author details}

${ }^{1}$ Kenya Agriculture Research Institute, P.O. Box 147, Marsabit, Kenya.

${ }^{2}$ Tennessee State Department of Health, Nashville, TN 37243, USA. 
${ }^{3}$ Department of Agricultural and Resource Economics, Colorado State University, Fort Collins, CO 80523-1172, USA.

\section{Received: 19 February 2014 Accepted: 2 May 2014} Published: 28 May 2014

\section{References}

Aguiar, M, and O Sala. 1999. Patchy structure, dynamics and implications for the functioning of arid ecosystem. Tree 14(7): 273-277.

Anderson, JM, and JSI Ingram. 1993. Tropical soil biology and fertility: A handbook of methods. Wallingford: CAB International.

Behnke, R, and C Kerven. 2013. Counting the costs: Replacing pastoralism with irrigated agriculture in the Awash valley, north-eastern Ethiopia. London: IIED (International Institute for Environment and Development) Climate Change Working Paper no. 4.

Behnke, R, I Scoones, and C Kerven. 1993. Range ecology at disequilibrium: New models of natural variability and pastoral adaptation in African savannas. London: Overseas Development Institute; International Institute for Environment and Development; Commonwealth Institute.

Brown, SL, P Schroeder, and JS Kern. 1999. Spatial distribution of biomass in forests of the eastern USA. Forest Ecology and Management 123: 81-90.

Cairns, MA, S Brown, E Helmer, and GA Baumgardener. 1997. Root biomass allocation in the world's upland forests. Oecologia 111: 1-11.

Coppock, DL. 1994. The Borana Plateau of Southern Ethiopia: Synthesis of pastoral research, development and change, 1980-91. Addis Ababa: ILCA (International Livestock Centre for Africa).

Derry, JF, and RB Boone. 2010. Grazing systems are a result of equilibrium and non-equilibrium dynamics. Journal of Arid Environments 74: 307-309.

Ellis, JE, and DM Swift. 1988. Stability of African pastoral systems: Alternate paradigms and implications for development. Journal of Range Management 41: 450-459.

Gerber, PJ, H Steinfeld, B Henderson, A Mottet, C Opio, J Dijkman, A Falcucci, and G Tempio. 2013. Tackling climate change through livestock - A global assessment of emissions and mitigation opportunities. Rome: Food and Agriculture Organization of the United Nations (FAO).

Haro, G, G Doyo, and J Mcpeak. 2004. Linkages between community, environment, conflicts management: Experiences from northern Kenya. World Development 3(2): 285-299.

Henry, M, N Picard, C Trotta, R Manlay, R Valentine, M Bernoux, and L Saint-Andre. 2011. Estimating tree biomass of sub-Saharan African forests: A review of available allometric equations. Silva Fennica 45(3B): 477-569.

Herrero, M, P Thornton, P Gerber, and R Reid. 2009. Livestock, livelihoods and the environment: Understanding the trade-offs. Current Opinion in Environmental Sustainability 1: 111-120.

Hesse, C, and J MacGregor. 2006. Pastoralism: Drylands' invisible assets? Developing a framework for assessing the value of pastoralism in East Africa. London: IIED. Issue paper no. 142.

Hogg, R. 1986. The new pastoralism: Poverty and dependency in Northern Kenya. Africa 56(3): 319-333.

Illius, AW, and TG O'Connor. 1999. On the relevance of nonequilibrium concepts to arid and semi-arid grazing systems. Ecological Applications 9(3): 798-813.

IPCC. 2007. Climate change 2007: Synthesis report. An assessment of Intergovernmental Panel on Climate Change, Valencia, Spain. www.ipcc.ch/ pdf/assessment-report/ar4/syr/ar4_syr.pdf. Accessed 24 Apr 2004.

IPCC. 2013. Summary for Policymakers. In: Climate Change 2013: The Physical Science Basis. Contribution of Working Group 1 to the Firth Assessment Report of the Intergovernmental Panel on Climate Change [Stocker T.E, D. Qin, G.K. Plattner, M. Tignor, S.K. Allen, J.Boschung, A. Nauels, Y.xia, V.Bex and P.M. Midgley (eds.)], Cambridge University Press, Cambridge, United Kingdom and New York, NY, U.S.A http://www.climate2013.org/images/report/ WG1AR5_SPM_FINAL.pdf. accessed 20.05.2014.

Jiao, Y, Z Xu, and J Zhao. 2009. Effects of grassland conversion to cropland and forest on soil organic carbon and dissolved organic carbon in the farming-pastoral ecotone of Inner Mongolia. Acta Ecologica Sinica: 150-154.

Kobash, T, K Kamura, JP Severinghans, JM Barnola, BM Vinther, SJ Johnsen, and JE Box. 2011. High variability of Greenland surface temperature over the past 4000 years estimated from trapped air in an ice core. Geophysical Research Letters 38: L21501. www.leif.org/EOS/2011GL049444.pdf.
Kratli, S, and N Schareika. 2010. Living off uncertainty: The intelligent animal production of dryland pastoralists. European Journal of Development Research 22: 605-622.

Kurgat, B. 2011. Relationship between vegetation cover types and soil organic carbon in the rangelands of Northern Kenya, MSc thesis. Germany: Hohenheim University.

Lal, R. 2001. Potential of desertification control to sequester carbon and mitigate the green house effect. Climate Change 51: 35-72.

Lamprey, H. 1983. Pastoralism yesterday and today: The over grazing problem. In Tropical savannas: Ecosystem of the world, ed. F Bourlieve, 643-666. Amsterdam: Elsevier.

Lengaiboni, M, A Bregt, and P Molen. 2010. Pastoralism within land administration in Kenya: The missing link. Land Use Policy 27: 579-588.

Little, P. 1985. Social differentiation and pastoralist sedentarization in northern Kenya. Africa 55(3): 243-261.

Mangini, A, C Spotl, and P Verdes. 2005. Reconstruction of temperature in the central Alps during the past 2000 years from the a ${ }^{18} \mathrm{O}$ stalagmite record. Earth and Planetary Science Letters 235: 741-751.

Matieu, H. 2010. Carbon stocks and dynamics in sub Sahara Africa, PhD dissertation. Paris: University of Tuscia.

Niles, J, E Cleland, H Gibbs, and B Orcutt. 2010. Carbon finance in Ethiopian rangelands: Opportunities for Save the Children/US Leadership. In Final report. Ethiopia. http://www.fao.org/fileadmin/user_upload/drought/docs/ carbon_finance_Final_TFG_Report_SCUS_Jul09.pdf. Accessed 20 Jan 2014.

Nori, M. 2006. Mobile livelihoods, patchy resources \& shifting rights: approaching pastoral territories. International Land Coalition. Working draft for discussion http://www.landcoalition.org/sites/default/files/legacy/legacypdf/ pol_pastoral_dft.pdf?q=pdf/pol_pastoral_dft.pdf. Accessed 11 Jan 2014.

Oba, G, RB Weladji, WJ Lusigi, and NC Stenseth. 2003. Scale-dependent effects of grazing on rangeland degradation in northern Kenya: A test of equilibrium and non-equilibrium hypotheses. Land Degradation and Development 14(1): 83-94.

Odote, C. 2013. The dawn of Uhuru? Implications of constitutional recognition of communal land rights in pastoral areas of Kenya. Nomadic People 17(1): 87-105

Perez-Quezada, J, C Delpiano, K Snyder, D Johnson, and N Franck. 2011. Carbon pools in an arid shrubland in Chile under natural and afforested conditions. Journal of Arid Environments 75: 29-37.

Piñeiro, G, J Parnelo, M Osterheld, and E Jobbagy. 2010. Pathways of grazing effects on soil carbon and nitrogen. Range Ecology and Management 63(1): 109-119.

Pratt, DJ, and MD Gwynne. 1977. Rangeland management and ecology in East Africa. London: Hodder and Stoughton.

Qi, J, RC Marsett, MS Moran, DC Goodrich, P Heilman, YH Kerr, G Dedieu, A Chelbouni, and XX Zhang. 2000. Spatial and temporal variations of vegetation in the San Pedro River basin area. Agriculture and Forestry Meteorology 105: 55-68.

Reeder, J, and G Schuman. 2002. Influence of livestock grazing on C sequestration in semi-arid mixed-grass and short-grass rangelands. Environmental Pollution 116: 457-463.

Rice, CW. 2005. Dynamics and management. In Carbon cycles in soils, 164-170. Manhattan: Kansas State University.

Roba, H, and G Oba. 2008. Integration of herders knowledge and ecological methods for land degradation assessment around sedentary settlements in a sub-humid zone in northern Kenya. International Journal of Sustainable Development \& World Ecology 15(3): 251-264.

SAS. 1999. The SAS system for Windows, version 8. Cary, NC: SAS Institute Inc.

Schuman, G, H Janzen, and J Herrick. 2002. Soil carbon dynamics and potential carbon sequestration by rangelands. Environmental Pollution 116: 391-396.

Scoones, I. 1999. Ecological dynamics of grazing resource tenure: A case study from Zimbabwe. In Managing mobility in African rangelands: The legitimization of transhumance, ed. M Niamir-Fuller. London: Intermediate Technology Publications.

Scoones, I, and O Graham. 1994. New directions for pastoral development in Africa. Development in Practice 4: 188-198.

Steinfeld, H, P Gerber, T Wassenarr, V Castel, M Rosales, and C de Haan. 2006. Livestock's long shadow: Environmental issues and options. Rome: Food and Agriculture Organisation of the United Nations.

Tennigkeit, T, and A Wilkes. 2008. An assessment of the potential for carbon finance in rangeland. China: Working Paper no. 68 for World Agro-forestry Centre. http://www.worldagroforestry.org/downloads/publications/PDFs/ WP15892.PDF. Accessed 28 Apr 2014. 
Vetter, S. 2005. Rangeland at equilibrium and non-equilibrium: Recent development in the debate. Journal of Arid Environments 62: 321-341.

Wang, Z, X Han, and L Li. 2008. Effect of grassland conversion to crop lands on soil carbon in the temperate Inner Mongolia. Journal of Environmental Management 86: 529-534.

Ward, D, B Ngairorue, J Kathena, R Samuels, and Y Ofran. 1998. Land degradation is not necessary outcome of communal pastoralism in arid Namibia. Journal of Arid Environments 40(4): 357-371.

White, R, S Murray, and M Rohweder. 2000. Pilot analysis of global ecosystems in grassland ecosystem. Washington D.C: World Resource Institute.

\subsection{6/2041-7136-4-5}

Cite this article as: Dabasso et al:: Carbon stocks in semi-arid pastoral ecosystems of northern Kenya. Pastoralism: Research, Policy and Practice 2014, 4:5

\section{Submit your manuscript to a SpringerOpen ${ }^{\circ}$} journal and benefit from:

- Convenient online submission

- Rigorous peer review

- Immediate publication on acceptance

- Open access: articles freely available online

- High visibility within the field

- Retaining the copyright to your article 